\title{
Transmembrane and Coiled-Coil Domains Protein 1
}

National Cancer Institute

\section{Source}

National Cancer Institute. Transmembrane and Coiled-Coil Domains Protein 1. NCI

Thesaurus. Code C114415.

Transmembrane and coiled-coil domains protein 1 (653 aa, $\sim 72 \mathrm{kDa}$ ) is encoded by the human TMCC1 gene. This protein has no known function. 